\title{
Medical Healthy Detection dengan Parameter Tinggi Badan dan Berat Badan
}

\author{
Erika Loniza $^{1}$, Fahrurrozi $^{2)}$, Desy Rahmasari ${ }^{3)}$ \\ ${ }^{1.2}$ Program Studi Teknologi Elektro-Medis Program Vokasi Universitas Muhammadiyah Yogyakarta \\ Jalan Brawijaya, Geblagan, Tamantirto, Kasihan, Bantul, Yogyakarta, 55185 \\ Telp. (0274) 387656, Fax (0274) 387646 \\ ${ }^{3}$ Rumah Sakit Umum Daerah Kota Yogyakarta \\ 1)erika@umy.ac.id
}

\begin{abstract}
Abstrak - Pemeliharaan kesehatan adalah upaya penanggulangan dan pencegahan gangguan kesehatan. Salah satu dari sekian banyak yang menyebabkan kesehatan terganggu adalah masalah obesitas atau kegemukan, dan masalah obesitas merupakan hal yang paling banyak terdapat dikalangan masyarakat lokal bahkan di dunia. Penelitian ini bertujuan untuk membuat dan mendesain alat ukur tinggi dan berat badan serta Indeks Massa Tubuh objek dengan tampilan hasil pada LCD dan tersimpan di SD Card. Pada sensor ultrasonic maskimal tinggi badan yang dapat diukur yaitu sebesar $200 \mathrm{~cm}$ dan pada sensor load cell maksimal berat badan yang dapat di ukur yaitu sebesar $150 \mathrm{~kg}$, dalam pembuatan alat tersebut semua sistem dikontrol oleh minimum system arduino Uno. Dari penelitian yang dilakukan terhadap 5 orang sebagai objek pengukuran didapatkan hasil pengukuran rata-rata berat badan sebesar 51,76 kg dengan rata-rata persentase error sebesar 0,6\% dan rata-rata tinggi badan sebesar 159,4 cm dengan rata-rata persentase error sebesar 0,2\%. Setelah dilakukan penelitian secara umum dapat disimpulkan bahwa alat Medichal Healthy Detection dapat digunakan dengan baik dan masih dalam nilai ambang batas toleransi +- $1 \%$.
\end{abstract}

Kata-kata kunci : obesitas, ultrasonic, load cell, arduino uno, sd card

\section{PENDAHULUAN}

\section{Latar Belakang}

Seiring dengan berkembangnya teknologi baik di bidang medis maupun industri pada saat ini maka meningkat pula daya pikir manusia akan teknologi sebagai penunjang kebutuhan kehidupan. Dari perkembangan tersebut tentunya muncul teknologi-teknologi baru yang dapat mengurangi beban tenaga manusia

Pemeliharaan kesehatan adalah upaya penaggulangan dan pencegahan gangguan kesehatan seperti pada firman Allah dalam alquran yang artinya "makan dan minumlah kalian, namun jangan berlebih-lebihan (boros) karena Allah tidak mencintai orang-orang yang berlebihan." (Al-A'raf:31). Salah satu dari sekian banyak yang menyebabkan kesehatan terganggu adalah masalah obesitas atau kegemukan, dan masalah obesitas merupakan hal yang paling banyak terdapat dikalangan masyarakat bahkan di dunia. Dalam pembahasannya obesitas didefinisikan sebagai terdapatnya penumpukan lemak yang berlebihan didalam tubuh [1] Seseorang dianggap menderita kegemukan (obes) bila Indeks Massa Tubuh (IMT), yaitu nilai yang diperoleh dari hasil pembagian berat badan dalam kilogram dengan kuadrat tinggi badan dalam meter, lebih dari $30 \mathrm{Kg} / \mathrm{m}^{2}$ [2]. Penyakit yang kerap timbul akibat obesitas yaitu diabetes sehingga medical check up yang fokus pada berat badan, tinggi badan, usia, jenis kelamin, tekanan darah diastolik dan sistolik, dan BMI [3].

Permasalahan kesehatan yang semakin kompleks turut pula menunjang perkembangan teknologi medis, dalam upaya membangun sebuah alat yang akan dipergunakan untuk melakukan proses monitoring pasien, diagnosa, dan penanganan sebuah penyakit.

Dari hal-hal di atas yaitu mengenai kegunaan dan peran kontrol automatik terutama dalam bidang medis, hal itu sangatlah penting karena dapat memberikan kemudahan dalam mempercepat laju kerja, dalam hal ini adalah masalah efisiensi waktu dan masalah menggantikan tenaga manusia dalam pengukuran tinggi badan dan berat badan. Untuk menindaklanjuti hal di atas, perlu melakukan satu penelitian untuk merancang dan membuat alat pengukur indeks massa tubuh dengan menggunakan sensor ultrasonik sebagai pengukur tinggi badan dan timbangan digital dengan sensor load cell sebagai pengukur massa tubuh. Sensor tersebut akan diproses menggunakan chip elektronika ATMega328[4].

Berdasarkan identifikikasi masalah di atas maka penulis ingin merancang alat Medical Healthy Detection yang dapat memudahkan user dalam melakukan pengukuran beberapa paramameter dalam satu waktu [5]

\section{METODE}




\section{Indeks Massa Tubuh}

Cara penilaian status gizi dengan menghitung Indeks Massa Tubuh (IMT) atau Body Mass Index (BMI)[6]. Cara ini digunakan untuk mengetahui status gizi seseorang. Indeks Massa Tubuh memiliki kelebihan adalah sebagai berikut. (a) Pengukuran sederhana dan mudah dilakukan. (b) Dapat menentukan kelebihan dan kekurangan berat badan. Akan tetapi, indeks ini tak lepas dari kekurangannya, yaitu. (c) Indeks tidak dapat diterapkan pada bayi, ibu hamil, dan anak-anak yang masih dibawah umur. (d) Tidak dapat untuk menentukan status gizi dan berat badan yang proporsional bagi orang yang menderita edema, asites, dan hepatomegaly[7]. Dari persamaan (1) kita dapat mengetahui cara menghitung IMT menggunakan rumus perhitungan seperti di bawah ini :

$$
I M T=\frac{\text { Berat Badan }(\mathrm{Kg})}{\text { Tinggi Badan }(M)^{2}}
$$

Berdasarkan dari persamaan (1) ini dapat disimpulkan yaitu pada Tabel 1 yang merupakan konsultasi formulasi status gizi untuk Indeks Massa Tubuh (IMT) [8]

Tabel 1 Formulasi Status Gizi

\begin{tabular}{cc}
\hline \multicolumn{2}{c}{ Status Gizi } \\
\hline Kurus & $<18,5$ \\
\hline Normal & $18,5-25,0$ \\
\hline Obesitas & $>30$ \\
\hline Rata-Rata & 22,0 \\
\hline
\end{tabular}

\section{Blok Diagram}

Blok diagram berfungsi untuk memetakan dari proses suatu kerja dan memudahkan seseorang dalam memahami cara kerja alat.

Gambar 1 menunjukkan blok diagram alat. Objek berdiri tegak lurus diatas media datar yang terdapat pada alat dan menyesuaikan pemasangan sensor. Power supply 5 volt digunakan sebagai sumber tegangan agar rangkaian dapat berkerja.

Salah satu bagian utama dalam perancangan alat yaitu sensor load cell (untuk pengukuran berat badan), sensor ultrasonik HC-SR04 (untuk pengukuran tinggi badan. Output dari keempat sensor akan diproses oleh mikrokontroler. Output atau data dari sensor load cell yang di hasilkan masih berupa data analog, data tersebut di konversikan menjadi data digital pada blok
Analog to Digital Converter (ADC) oleh HX711 sebelum data di proses oleh mikrokontroler[9][10]

Mikrokontroler ATMega328 sebagai pengatur dan pemroses data dari sensor dan seluruh rangkaian sehingga dapat menghasilkan output berupa tulisan digital pada LCD dan melakukan penyimpanan data pada SD Card [9]. Ketika alat dan objek masih melakukan persiapan maka indikator led bewarna merah akan menyala. Ketika alat sedang melakukan pengukuran led warna kuning akan menyala dan setelah proses pengukuran selesai led akan berwarna hijau[11].

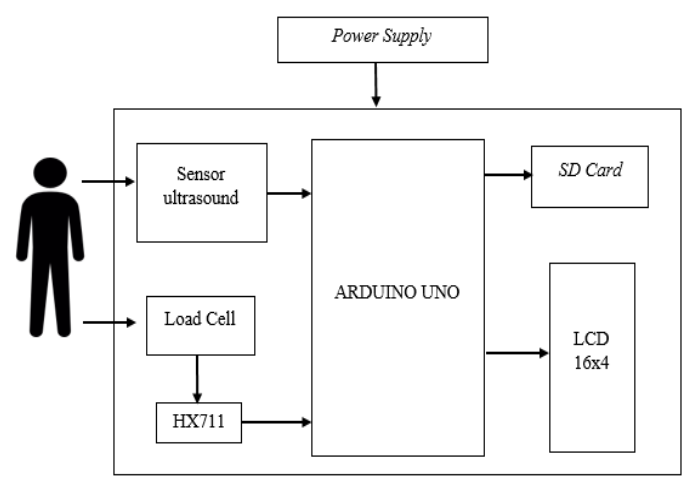

Gambar 1 Blok Diagram Alat

\section{Diagram Alir}

Pada saat alat dihidupkan akan terjadi inisialisasi input/output mikrokontroler dan antarmuka LCD 16x4. Objek melakukan set point atau posisi awal tegak lurus sesuai dengan media dan sensor. Jika posisi objek sudah sesuai, terdapat tombol start berfungsi untuk memulai pengukuran dan indikator $L E D$ akan berwarna kuning ketika sedang melakukan pengukuran. Sensor akan mendeteksi detak jantung dan suhu tubuh dalam waktu 10 detik dengan pemrosesan data pada mikrokontroler. Hasil dari pengukuran dua parameter tersebut akan di tampilkan pada LCD 16x4. Display menampilkan bradycardia jika HR <60 bpm, normal jika HR 60-100 bpm dan tachycardia jika HR >100 bpm.. Diagram alir kinerja sistem pada alat dapat dilihat pada Gambar 2. 


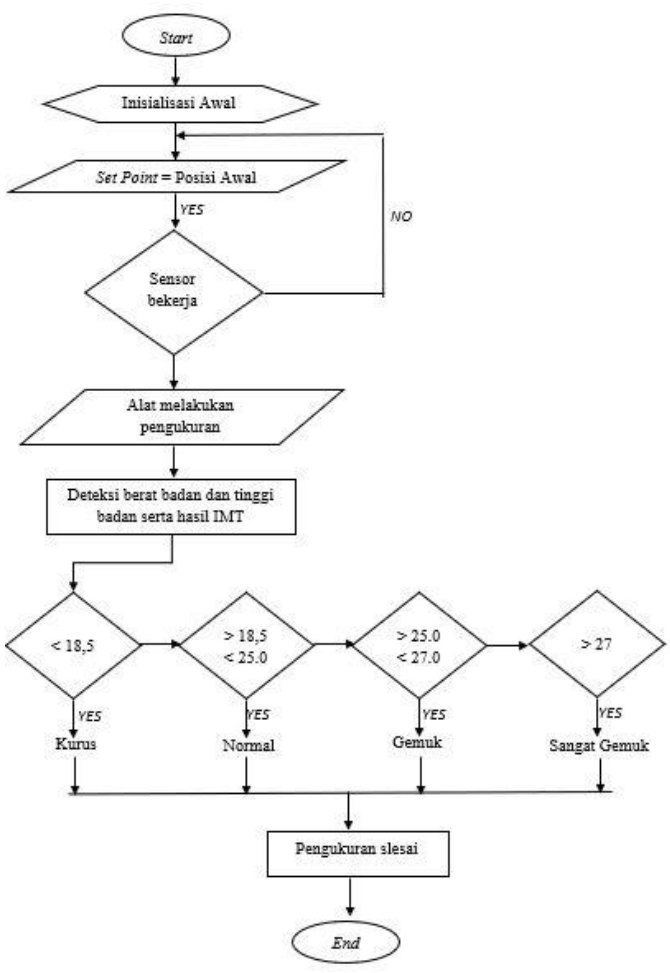

Gambar 2. Diagram Alir

\section{HASIL DAN PEMBAHASAN}

\section{Hasil Pengukuran dan Analisis}

Data berikut ini merupakan data yang diperoleh dari hasil pengukuran yang dilakukan terhadap 5 orang pasien, Data hasil pengukuran keseluruhan dapat dilihat pada Tabel.2

Tabel.2 Hasil Pengukuran Keseluruhan

\begin{tabular}{|c|c|c|c|c|c|c|}
\hline \multirow[b]{2}{*}{$\begin{array}{l}\mathrm{N} \\
\mathrm{o}\end{array}$} & \multirow[b]{2}{*}{ Nama } & \multirow[b]{2}{*}{$\begin{array}{l}\text { Ket } \\
\text { IMT }\end{array}$} & \multicolumn{2}{|c|}{$\begin{array}{c}\text { Rata-rata Prototype } \\
\text { TA }\end{array}$} & \multicolumn{2}{|c|}{ Error } \\
\hline & & & $\begin{array}{l}\text { Berat } \\
\text { Badan } \\
(\mathrm{Kg})\end{array}$ & $\begin{array}{l}\text { Tinggi } \\
\text { Badan } \\
(\mathrm{Cm})\end{array}$ & $\begin{array}{l}\text { Berat } \\
\text { Badan } \\
(\%)\end{array}$ & $\begin{array}{l}\text { Tinggi } \\
\text { Badan } \\
(\%)\end{array}$ \\
\hline 1 & $\begin{array}{l}\text { Pak } \\
\text { Musi- } \\
\text { ran }\end{array}$ & Gemuk & 69,9 & 155,2 & 0,1 & 0,1 \\
\hline 2 & $\begin{array}{l}\text { Gita } \\
\text { Melani }\end{array}$ & $\begin{array}{l}\text { Sangat } \\
\text { Kurus }\end{array}$ & 30,1 & 141,2 & 0,3 & 0,1 \\
\hline 3 & Hana & Kurus & 44,5 & 157,8 & 1,1 & 0 \\
\hline 4 & Yudi & Normal & 54,1 & 168 & 0,1 & 0,3 \\
\hline 5 & Dirja & Normal & 60,2 & 174,6 & 0,3 & 0,2 \\
\hline \multicolumn{3}{|c|}{ Rata-rata } & 51,76 & 159,4 & 0,3 & 0,2 \\
\hline
\end{tabular}

Berdasarkan pengukuran dan pengujian alat pada Tabel.3 terdapat persentase error berat badan yang terkecil yaitu $0,1 \%$ pada saat pengukuran yang dilakukan oleh saudara Yugi dan Pak Musiran dengan nilai rata-rata pengukuran berat badan sebesar 54,1 kg dan 69,9 $\mathrm{kg}$, dan persentase error berat badan terbesar didapatkan pada saat pengukuran oleh Hana yaitu sebesar $1,1 \%$ dengan nilai rata-rata pengukuran berat badan sebesar 44,5 kg. Kemudian persentase error yang didapatkan pada saat pengukuran tinggi badan, terdapat persentase error paling kecil dengan nilai yaitu $0 \%$ pada saat pengukuran saudara Yugi dengan nilai rata-rata pengukuran tinggi 168, sedangkan persentase error tinggi badan terbesar didapatkan pada saat pengukuran oleh saudara Dirja dengan nilai persentase error sebesar $0,3 \%$ dengan nilai rata-rata pengukuran tinggi badan yaitu sebesar $174.6 \mathrm{~cm}$.

\section{KESIMPULAN}

Setelah melakukan proses pembuatan dan studi literatur perencanaan, pengujian alat dan pendataan, penulis dapat menyimpulkan sebagai berikut: Persentase error yang dihasilkan setelah melakukan pengukuran dan perhitungan untuk persentase error tinggi badan terendah yaitu $0,1 \%$ dan persentase error tinggi badan terbesar yaitu $0,3 \%$. Sedangkan persentase error pada berat badan paling kecil yaitu $0,2 \%$ dan persetase error berat badan terbesar yaitu $1,4 \%$.

Terdapat error berat badan yang terkecil yaitu $0,1 \%$ pada saat pengukuran yang dilakukan oleh saudara Yugi dan Pak Musiran dengan nilai rata-rata pengukuran berat badan sebesar $54,1 \mathrm{~kg}$ dan $69,9 \mathrm{~kg}$

Error berat badan terbesar didapatkan pada saat pengukuran oleh Hana yaitu sebesar 1,1\% dengan nilai rata-rata pengukuran berat badan sebesar 44,5 kg.

Error yang didapatkan pada saat pengukuran tinggi badan, terdapat error paling kecil dengan nilai yaitu $0 \%$ pada saat pengukuran saudara Yugi dengan nilai rata-rata pengukuran tinggi 168 .

Error tinggi badan terbesar didapatkan pada saat pengukuran oleh saudara Dirja dengan nilai persentase error sebesar $0,3 \%$ dengan nilai rata-rata pengukuran tinggi badan yaitu sebesar $174.6 \mathrm{~cm}$

\section{REFERENSI}

[1] A. Yonata and A. P. P. Satria, "Hipertensi sebagai Faktor Pencetus Terjadinya Stroke," Majority, vol. 5, no. 2, p. 17, 2016.

[2] D. Gallagher, S. B. Heymsfield, M. Heo, S. A. Jebb, P. R. Murgatroyd, and Y. Sakamoto, "Healthy percentage body fat ranges: An approach for developing guidelines based on body mass index," Am. J. Clin. Nutr., vol. 72, no. 3, pp. 694-701, 2000.

[3] M. Grotle, K. B. Hagen, B. Natvig, F. A. Dahl, and T. K. Kvien, "Obesity and osteoarthritis in knee, hip and/or hand: An epidemiological study in the general population with 10 years followup," BMC Musculoskelet. Disord., vol. 9, pp. 15, 2008.

[4] M. Situmorang, "Penentuan Indeks Massa 
JUST TI: (Jurnal Sains Terapan Teknologi Informasi) 13, Januari, 2021: 41-44

ISSN: 2579-4510(online) ISSN: 2085-6458(print)

Tubuh (IMT) melalui Pengukuran Berat dan Tinggi Badan Berbasis MikrokontrolerAT89S51 dan PC," J. Teor. Dan Apl. Fis., vol. 03, no. 02, pp. 102-110, 2015.

[5] R. Akula, N. Nguyen, and I. Garibay, "Supervised Machine Learning based Ensemble Model for Accurate Prediction of Type 2 Diabetes," arXiv, 2019.

[6] Z. Archilona, K. Nugroho, and N. Puruhita, "Hubungan Antara Indeks Massa Tubuh (Imt) Dengan Kadar Lemak Total," J. Kedokt. Diponegoro, vol. 3, no. 1, p. 137516, 2014.

[7] D. Utami and G. A. Setyarini, "Faktor-faktor yang mempengaruhi indeks massa tubuh pada remaja usia 15-18 tahun di SMAN 14 Tangerang," J. Ilmu Kedokt. Dan Kesehat., vol. 4, no. 3, pp. 207-215, 2017.

[8] T. Lasabuda, P. M. Wowor, and Y. Mewo, "Gambaran Indeks Massa Tubuh (Imt) Jamaah
Mesjid Al- Fatah Malalayang," J. e-Biomedik, vol. 3, no. 3, pp. 9-12, 2015.

[9] M. Surbakti, "Hubungan indeks massa tubuh (IMT) dengan prestasi belajar pada siswa sekolah menengah atas SMA negeri di Kota Denpasar Utara," Dwipayana, IMP, vol. 7, no. 4, pp. 155-159, 2018.

[10] I. D. A. A. Yu, M. A. D. Amayanti, I. K. E. J. Unitha, I. D. A. B. Agus, and M. A. D. E. S. Uaskara, "Pola Pertumbuhan Berdasarkan Berat Dan Tinggi Badan Siswa Pada Sekolah Negeri Dan Swasta Di Kota Denpasar, Bali Growth Pattern Based on Height and Body Weight From Students of Government and Private School At Denpasar, Bali," vol. 21, no. 2, pp. 78-87, 2017.

[11] W. Budhyanti, "Status Gizi dan Status Tanda Vital Mahasiswa Akfis UKI," J. Pro-Life, vol. 5, no. 2, pp. 543-556, 2018. 